\title{
THE APRIL MEETING IN SAN JOSE
}

The six hundred forty-sixth meeting of the American Mathematical Society was held on Saturday, April 22, 1967 at San Jose State College, in San Jose, California. There were 140 registrants at this meeting, 110 of whom were members of the Society.

By invitation of the Committee to Select Hour Speakers for Far Western Sectional Meetings, an hour address was given by Professor Abraham Robinson of the University of California, Los Angeles. The title of Professor Robinson's lecture was Nonstandard arithmetic.

There were six sessions for contributed papers, with Professors R. E. DeMarr, H. M. W. Edgar, H. S. Kieval, E. A. Michael, R. D. Sinkhorn, and R. W. Stringall presiding.

R. S. Pierce

Associate Secretary

Seattle, Washington 